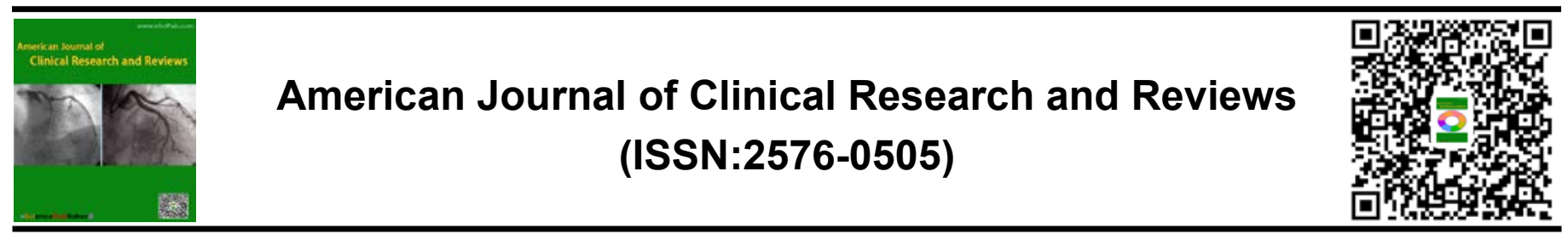

\title{
CHIKUNGUNYA FEVER: A NEW VÍRUS TO THE OLD VECTOR
}

\section{José Fabrício Silva', Pedro Henrique Wanderley Emiliano², Fabíola de Almeida Brito ${ }^{3}$}

1José Fabrício Silva. Biomédico, Centro Universitário Cesmac/Cesmac. Maceió-AL, Brasil. ${ }^{2}$ Pedro Henrique Wanderley Emiliano. Graduando em Biomedicina, Centro Universitário Cesmac/Cesmac.

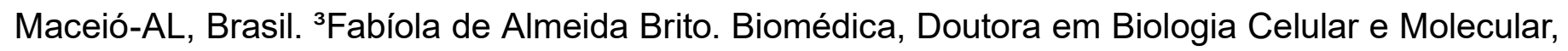
Centro Universitário Cesmac/Cesmac. Maceió-AL, Brasil.

\section{ABSTRACT}

Objective: The chikungunya fever is an arbovirus transmitted by chikungunya virus (CHIKV), using vectors like mosquitoes Aedes albopictus and Aedes egypti. This review aimed to gather up to date and official information on the Chikungunya fever in Brazil because of its resemblance to dengue and importance for public health.

Methods: A review of scientific literature was conducted by searching articles in the mains databases, NCBI, SCIELO, BIREME, CAPES periodical portal between months February and April 2015.

Results: Joint pain are the classic symptoms of chikungunya, and are being used as one of the clinical, laboratory and epidemiological for differential diagnosis. There are no vaccines for the disease, and palliative drugs used against inflammatory response caused by the virus. Mosquito control is the main preventive measure. Thus, it is necessary that the health workers are trained for the effective diagnosis and prevention.

Keywords: Chikungunya virus, Aedes egypti, Fever.
*Correspondence to Author:

Fabíola de Almeida Brito. Biomédica, Doutora em Biologia Celular e Molecular, Centro Universitário Cesmac/Cesmac. Maceió-AL, Brasil. fabiolabrito @ hotmail.com

How to cite this article:

José Fabrício Silva et al., CHIKUNGUNYA FEVER: A NEW VÍRUS TO THE OLD VECTOR. American Journal of Clinical Research and Reviews, 2017; 1:5.

\section{eSciencePublisher 8}

eSciPub LLC, Houston, TX USA. Website: http://escipub.com/ 


\section{INTRODUCTION}

The Chikungunya virus (CHIKV) was first isolated in humans in the 50 and 60 in Tanzania, is an RNA virus belonging to the family Togaviridae Alphavirus genus. The Chikungunya name is a word derived from the Makonde meaning that which bends and describe the curved appearance of patients who have severe pain in the joints resulting from intense arthralgia (joint pain). For three decades, the virus caused outbreaks in several African and Asian countries ${ }^{1}$.

The spread of the virus worldwide is primarily due to air transport, currently CHIKV is found in Burma, Thailand, Cambodia, Vietnam, India, Sri Lan and the Philippines. From 2004 to 2008, the virus is easily spread in Asia, Europe, North America ${ }^{2}$. In recent outbreaks were found imported cases of individuals with CHIKV in the Caribbean, US and French Guiana, but in the Americas, Chingunkunya can become endemic, due to the presence of mosquito vectors ${ }^{3}$. The arrival of the virus in Brazil, was also given by downloading, but have since been diagnosed several cases of indigenous transmission. According to the Ministry of Health, in 2015 it was registered 337 cases of Chinkngunya fever in Brazil. Of this total, 38 cases were imported by passengers who came from the Dominican Republic, Haiti, Venezuela, the Caribbean Islands and French Guiana $^{4}$. In Brazil updated data Health Portal totaling 38 imported cases recorded, and Sao Paulo with 17 cases. The number of indigenous cases now total 173 and the state of Bahia will find the largest number of cases, $156^{5}$.

In Alagoas, specifically, there is already a contingency plan prepared by the State Health Secretariat, despite having no cases officially, the healthcare industry is preparing to deal with possible cases occurring. The transmission of CHIKV is due to mosquito bites Aedes albopictus and Aedes egypti also responsible for transmitting the dengue virus and zika respectively. Humans are the main reservoirs of $\mathrm{CHIKV}$ virus during the epidemic season, since the interepidêmico period, vertebrates such as rodents, birds and small mammals are isolated as major reservoir of the virus, which subsequent to an incubation period of approximately 10 days, the mosquito becomes capable of infecting humans ${ }^{6,7}$. There are reports that transmission during pregnancy causes miscarriage, the rate of vertical transmission to the newborn can reach up to $85 \%$, resulting in severe forms of newborns by $90 \%{ }^{1}$.

The two transmission vectors are widely distributed, being more present in areas of favorable temperatures and tropical climate. Any person regardless of age, color or race, is at risk of developing the disease. Once exposed to CHIKV, the individual acquired immunity, since it confers immune memory ${ }^{1}$.

From mosquito virus inoculation most individuals will over a period of ten days incubation symptomatic and may develop acute diseases, subacute and chronic, early in the infection, the patient may present with fever and severe pain in the joints ${ }^{1}$.

As Chingunkya fever it is a pathological manifestation that has been emerging recently, there are few studies in literature about the theme, therefore this study aims to gather information about the Chinkungunya fever because of its resemblance to dengue and importance in the context Public Health.

\section{METHODS}

A literature review was performed using scientific articles, doctoral dissertations and testing, contingency plans drawn up by countries and states in the areas of Immunology. The databases to be consulted: NCBI, SCIELO, BIREME, CAPES Periodicals Portal, Brazilian Digital Library of Theses and Dissertations and Google Scholar. Searches were conducted using the following key words: "virus", "Chikungunya", "fever", "Aedes", "joint pain", "epidemic" and "alphaviruses." The survey was conducted between the months February to April 2015.

The languages of the selected material were the Portuguese (Brazil), Spanish and English for the selection of sources was considered as inclusion criteria the relevance of the work and work line similar to the study, were excluded incomplete jobs, no conclusions available in full by hardcopy or via online.

\section{RESULTS}

Existing treatments are non-specific, so it is 
crucial initial diagnosis to prevent the disease from worsening. The fact that the disease have differential diagnosis with dengue favors the misdiagnosis and problem identification and control of dengue and Chikungunya fever. There are more than a way to diagnose the Chikungunya fever, these tools can be used in isolation or in combination. They can be used: clinical, serological examination, and clinical and epidemiological criteria ${ }^{1,8}$.

Clinical Analysis: Must have pay attention to the differential symptoms compatible with CHKV which is held with two other acute febrile diseases associated with arthralgia. In the acute phase the main differential diagnosis should be made with dengue ${ }^{5}$. Usually arthralgia is more associated with Chikungunya, since bleeding is more related to dengue fever, the general symptoms are: high fever lasting days to weeks, headache, back pain, chills, arthralgia, myalgia, nausea and vomiting ${ }^{9}$. Other diseases are also part of the differential diagnosis of Chikungunya fever: Malaria, Leptospirosis, rheumatic fever and septic arthritis. Table 1 shows the clinical and laboratory features that allow differentiation of the diagnosis ${ }^{1}$.

Table 1. Differential Diagnosis: Dengue Chikungunya $x$

\begin{tabular}{lll}
\hline $\begin{array}{l}\text { Clinical / } \\
\text { laboratory } \\
\text { demonstration }\end{array}$ & Chikungunya & Dengue \\
\hline Fever intensity & +++ & ++ \\
Exanthema & $++($ D1-D4) & + (D5-D7) \\
Myalgia & + & ++ \\
Arthralgia & +++ & + - \\
Retrorbital pain & + & +++ \\
Bleeding & - /+ & ++ \\
Shock & - & - / \\
Thrombocytopenia & + & +++ \\
Leukopenia & ++ & +++ \\
Lymphopenia & +++ & ++ \\
Neutropenia & + & +++ \\
Outcome after & Chronic & Fatigue \\
acute phase & arthralgia &
\end{tabular}

Source: ${ }^{1}$

Laboratory abnormalities of Chikungunya in the acute phase are nonspecific. Lymphopenia were observed less than 1,000 cells $/ \mathrm{mm}^{3}$, erythrocyte sedimentation rate and C-reactive protein are usually high, can be detected mild elevation of liver enzymes, creatinine and creatine phosphokinase (CPK) ${ }^{1}$.

LABORATORY TEST: To detect this arbovirus can be performed serological tests, virus isolation for culture (virological diagnosis) and molecular techniques (RT-PCR) to find the viral RNA. The most common is the search for specific antibodies in the blood, IgM antibody test by enzyme immunoassay - ELISA IgG or total antibodies IgG-ELISA, neutralizing antibody test showing recent titles or hemagglutination inhibition ${ }^{1,10}$ The reference laboratory for detecting CHIKV is the Evandro Chagas Institute, belonging to the Ministry of Health, located in Pará 5 .

C L IN I C A L - E P I DE M I O L O G I C A L CRITERIA: Clinical diagnosis becomes better defined as the occurrence of outbreaks and epidemics. In outbreak areas, must be used exclusively ${ }^{8}$.

\section{DISCUSION}

Chikungunya symptoms are similar with dengue, however more intense and more painful, although they have different characteristics. They can be ranked chronologically in three phases:

ACUTE PHASE: After an incubation period of 3-7 days, the patient get a high fever and sudden (above $39^{\circ} \mathrm{C}$ ) followed by severe pain in the joints of headaches behind the eyes, conjunctivitis, nausea, vomiting, headache and myalgia, redness in the body, these are the main features of the acute phase of the disease. Joint pain affect mainly the hands and feet, ankles and wrists, some larger joints such as shoulders, knees and spine, may come to be affected ${ }^{11,12}$.

Approximately $90 \%$ of patients will present these joint symptoms that will be essential to assist in dengue differentiation in some cases very often the emergence of maculopapular, starting on the 2nd and 5th day and may remain until the 10th day of symptoms. This evidence may extend 7-10 days should be taken into account in some severe cases the involvement of the central nervous system, the majority of patients will be unable to make their activities due to very intense arthralgia ${ }^{11,12}$. Subacute phase: After a 10-day period some patients may report an improvement in their general condition, reduction of fever, more in most patients may occurs worsening arthralgia and increased joint 
pain ${ }^{13}$. This phase may be a period of relapse, and patients in most cases complain of asthenia appearance, itching and maculopapular the trunks and limbs can also occur purpure, vesicular and bullous lesions, very particularly present in children, in more severe cases some patients may develop weakness, fatigue and depressive signs and to Raynaud's syndrome, symptoms like these are very common after the two and the first three months of onset ${ }^{14}$. Phase chronic: Despite its resemblance to the dengue virus chikungunya is less lethal, its most serious complications may be more common in the elderly and children or patients who already have another type of chronic disease and thus have an easier time developing forms more severe disease ${ }^{15}$.

During the chronic phase patients report the onset of pain sacroiliac, lumbosacral and cervical, thereby potentially leading to an increase of destructive arthralgia which is very similar to psoriatic arthritis or rheumatoid generally not significant changes in laboratory tests and $x$-rays of the affected regions plus some risk factors such as patients aged over 65 years with people with joint problems and more intense acute illness ${ }^{16}$.

Lack of vaccination to prevent infection and specific medication against the virus, complicates treatment, reinforced the importance of prevention and vector control ${ }^{9,17}$.

Dipyrone can be used alone or in combination with tramadol hydrochloride. The analgesic effect is not to say that inhibition of the inflammatory response, as the pain caused by the inflammatory response are induced by viruses or local joint tissue products. In more resistant patients should be given anti-inflammatory Steroidal orally for a period of seven days. This drug is contraindicated for patients with gastric or duodenal ulcer history and enhances care when used in the elderly, hyperglycemia and renal complications ${ }^{16}$. It is recommended to make use of acetylsalicylic acid (ASA) to prevent bleeding. The patient should stay in bed rest and drink plenty of liquids ${ }^{5}$.

\section{FINAL CONSIDERATIONS}

Health teams still need to have more clinical, laboratory and epidemiological criteria for diagnosing Chinkugunya Fever and be used precisely the treatments available since it was not yet produced a vaccine, so early diagnosis is critical for the control and treatment of the disease, all health units need to be prepared to receive and classify risk groups.

Joint pain can remain for many years and this can cause congestion in the health system, since the progress to chronic phase as specific long-term monitoring is necessary. Therefore it is essential to continuous monitoring, training of professionals and combating the mosquito that transmits the disease, the authorities should take more stringent measures to curb the spread of the virus, with these actions becomes possible to prevent major epidemics.

\section{REFERENCES}

1. Ministério da Saúde. Secretaria de Vigilância em Saúde (Brasil). Departamento de Vigilância das Doenças Transmissíveis. Plano de Contingência Nacional para a Febre Chikungunya. Brasília: Ministério da Saúde, 2014.

2. Albuquerque IGC. et al. Chikungunya virus infection: report of the first case diagnosed in Rio de Janeiro, Brazil. Albuquerque. Revista da Sociedade Brasileira de Medicina Tropical, n. 45, n1, p. 128-129, 2012.

3. Organización Pan-Americana de la Salud/ Organización Mudial de la Salud (OPS/OMS). Preparación y respuesta ant la eventual introducción del vírus chikungunya em las Américas. Whasngton, D.C. 2011.

4. Alagoas tem mais dois casos suspeitos da febre chikungunya. [online]. Disponível em: <http://www.tribunahoje.com/noticia/121639/ saude/2014/10/29/alagoas-tem-mais-dois-casossuspeitos-da-febre-chikungunya.html> Acesso em: 18 mar. 2015.

5. Portal da Saúde. FEBRE CHIKUNGUNYA. [online]. Disponível em: <http://portalsaude. saude.gov.br/index.php?option=com_content\&v iew $=$ article $\& i d=15000 \&$ catid $=11 \&$ Itemid $=1030$ > . Acesso em: 01 abr 2015.

6. Secretaria de estado da saúde, Sistema Único de Saúde. Informe técnico sobre chikungunya SES/GO. Preparação e Resposta à Introdução do Vírus Chikungunya no Brasil. GOIÁS, 2014.

7. Varanjac A. Chikungunya, Junho 2014. Secretaria de estado da saúde. Coordenação de controle de doenças-ccd/centro de vigilância epidemiológica. Informe técnico. São paulo/brasil, 2014.

8. Boletim Controllab Qualifique. [internet]. Disponível 
em: <http://177.69.167.178/pdf/qualifique_48.

pdf> Acesso em: 31 março 2015.

9. Pontes MC. et al. Chikungunya: arbovirose como problema de saúde em expansão-uma revisão bibliográfica. Revista rede de cuidados em saúde, v. 9 , n. 2, 2015.

10. Vasconcelos, p. F. C. Emergência do vírus chikungunya: risco de introdução no brasil. Rev pan-amaz saude, v. 5, n. 3, p. 9-10, 2014.

11. Rascado R. Febre chikungunya: chegou para ficar? N. 33 disponível em: <http://www.unifal-mg. edu.br/cefal/sites/default/files/file/boletim $\% 2033$. pdf> acesso em: 16 abr. 2015.

12. Prefeitura de Araucária, Secretaria municipal de saúde. Procedimentos a serem adotados em araucária/pr, frente a caso suspeito de febre do chikungunya. Acesso em: disponível: <http://www.araucaria.pr.gov.br/pma/wpcontent/uploads/2014/10/chikungnya-plano-deassitencia-arauc\%c3\%a1ria-vers\%c3\%a3o-01de-30-de-set-2014.pdf> acesso em: 16 abr. 2015.

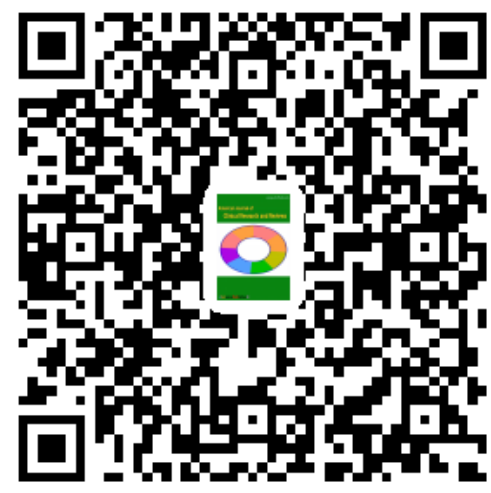

13. Prefeitura de São Paulo. Saúde. Informe técnico Chikungunya. 2014. Disponível em: <http://www. prefeitura.sp.gov.br/cidade/secretarias/upload/ saude/chikungunya_informe_tecnico_out_2014. pdf> acesso em: 16 abr. 2015.

14. Esta é sua biblioteca de manuais, apresentações e orientações sobre chikungunya. [online]. Disponível em: <http://www1.saude.ba.gov.br/ entomologiabahia/photoartwork2/chikun_docs. php> Acesso em: 16 abr. 2015.

15. Fiocruz isola vírus chikungunya e avança na criação de teste rápido. [online]. Disponível em: <http://g1.globo.com/bemestar/noticia/2015/03/ fiocruz-isola-virus-chikungunya-e-avanca-nacriacao-de-teste-rapido.html> Acesso em: 16 abr. 2015.

16. Ministério da Saúde, Secretaria de Vigilância em Saúde, (Brasil). Departamento de Vigilância das doenças Transmissíveis. Febre de chikungynya: manejo clínico. Brasília, 2015. 30 p.

17. Donalisio MR, Freitas AR R. Chikungunya no Brasil: um desafio emergente. Revista brasileira de epidemiologia, v. 18, n. 1, p. 283-5, 2015. 